\title{
GENETIC DIVERSITY OF Hymenaea courbaril L. IN THE MATO GROSSO AMAZON: IMPLICATIONS FOR CONSERVATION
}

\author{
Vinicius Delgado da Rocha ${ }^{1 *}$, Rosimeire Barboza Bispo², Eliane Cristina Moreno de Pedri ${ }^{3}$, Elisa dos Santos \\ Cardoso $^{3}$, Kelli Évelin Müller Zortéa ${ }^{3}$, Ana Aparecida Bandini Rossi ${ }^{3}$ \\ 1*Universidade Federal de Viçosa (UFV), Programa de Pós-Graduação em Genética e Melhoramento, Viçosa, Minas Gerais, Brasil - e-mail: \\ viniciusdelgado123@hotmail.com \\ ${ }^{2}$ Universidade Estadual do Norte Fluminense Darcy Ribeiro (UENF), Programa de Pós-graduação em Biotecnologia Vegetal, Campos dos \\ Goytacazes, Rio de Janeiro, Brasil - e-mail: rosimeirebarboza1@ hotmail.com \\ ${ }^{3}$ Universidade do Estado de Mato Grosso Carlos Alberto Reyes Maldonado (UNEMAT), Faculdade de Ciências Biológicas e Agrárias, \\ Programa de Pós-graduação em Biodiversidade e Biotecnologia da Rede Bionorte, Alta Floresta, Mato Grosso, Brasil - e-mail: \\ elicmbio@gmail.com; elisabyo@gmail.com; kellimuller@hotmail.com; anabanrossi@unemat.br \\ Received for publication: 18/03/2018 - accepted for publication: 13/05/2019
}

\begin{abstract}
Resumo
Diversidade genética de Hymenaea courbaril L na Amazônia mato-grossense: implicações para a conservação. Hymenaea courbaril L. é uma espécie arbórea, conhecida popularmente como jatobá. Sua madeira é bastante comercializada e produz frutos utilizados como recurso alimentar e medicinal. Esta espécie tem sido alvo da exploração madeireira e destruição de habitat. Conhecimentos acerca do polimorfismo genético são importantes para conservação de espécies afetadas pela ação antrópica. Neste estudo, analisou-se a diversidade genética de populações naturais de $H$. courbaril na Amazônia mato-grossense. Foram usados sete primers microssatélites para genotipar 43 indivíduos distribuídos em cinco populações na região norte do estado de Mato Grosso. Todos primers foram polimórficos, sendo detectados 72 alelos, com média de 10,29 por loco. As heterozigosidades esperada e observada apresentaram médias de 0,85 e 0,29 por loco, respectivamente. $\mathrm{O}$ índice de fixação foi positivo para todas as populações, sugerindo excesso de homozigotos, provavelmente por endogamia. A análise de variância molecular demonstrou que 85,33\% da diversidade genética estão dentro das populações. Pelo dendrograma UPGMA, os indivíduos foram divididos em seis grupos. No agrupamento do programa Structure foram formados quatros grupos, os quais não corresponderam à distribuição geográfica dos indivíduos, indicando que as populações não estão estruturadas geograficamente. Todas as populações amostradas apresentam elevados níveis de diversidade genética, podendo ser utilizadas para projetos de conservação. A variação genética é maior dentro das populações analisadas, portanto vários indivíduos devem ser conservados por população.

Palavras-chave: jatobá, microssatélites, recursos genéticos.
\end{abstract}

\begin{abstract}
Hymenaea courbaril L. (Fabaceae) is a tree species popularly known as 'jatobá'. Its wood is largely sold and its fruits are used as a food and medicinal resources. This species has been subjected to logging and habitat destruction. The knowledge about genetic polymorphism is important for the conservation of species affected by anthropic action. In this study, we analyzed the genetic diversity of natural populations of Hymenaea courbaril in the Mato Grosso Amazon. Seven microsatellite primers were used to genotyping of 43 individuals distributed in five populations in the north region of Mato Grosso State. All the seven primers were polymorphic, with 72 alleles detected, averaging 10.29 per locus. Expected and observed heterozygosities averaged 0.85 and 0.29 per locus, respectively. The fixation index was positive for all populations, suggesting excess homozygotes, probably due to inbreeding. Molecular analysis of variance revealed that $85.33 \%$ of genetic diversity is within the populations. Based on the UPGMA dendrogram, the individuals were divided into six groups. In the clustering provided by Structure software, four groups were formed which did not correspond to the geographic distribution of the individuals, indicating that the populations are not geographically structured. All sampled populations present elevated levels of genetic diversity, and so they can be used for conservation projects. Genetic variation is higher within the analyzed populations; therefore, several individuals must be conserved per population.

Keywords: Jatobá, microsatellites, genetic resources.
\end{abstract}

\section{INTRODUCTION}

The conservation of biodiversity has been one of the main concerns of humanity because of its important implications in the evolution and maintenance of ecological systems. Forest exploitation and habitat fragmentation may bring about significant changes in the genetic diversity, reproductive system, gene flow, density, and structure of natural populations (KAGEYAMA; GANDARA et al., 1998; CARVALHO et al., 2010).

FLORESTA, Curitiba, PR, v. 49, n. 4, p. 745 - 754, out/dez 2019.

Rocha, V. D. et.al.

ISSN eletrônico 1982-4688

DOI: $10.5380 /$ rf.v49 i4.58484 
Knowing how genes are distributed in individuals provides useful information for the planning of adequate strategies aimed at the conservation of species of ecological and economic interest (BITTENCOURT, 2007; GONÇALVES et al., 2010). In this regard, several molecular techniques are currently available to detect and analyze the distribution pattern of genetic variability in populations or individuals. Molecular markers have been efficient in many studies with plant species, making it possible to quantify the levels of genetic diversity and understand the gene structure. As a result, populations with high genetic diversity and thus important for conservation can be identified (COTA et al., 2017; SILVA et al., 2017).

Brazil has the largest continental biological diversity, harboring the most diverse tree flora with 8,715 species; the highest number of endemic trees (4,333 spp) and the largest tropical forest, the Amazon (BEECH et al., 2011). According to taxonomic data, the Amazon Forest has 14,003 species, 1,788 genera, and 188 families of seed plants, where the family Fabaceae is the richest in number of species, with 1,379 of them (CARDOSO et al., 2017).

One of the species found in the Amazon is Hymenaea courbaril L. (Fabaceae), popularly known as 'jatobá' or 'jatobazeiro'. Its fruits and trunk bark are used in popular medicine, and its fruit pulp can also be consumed in the human diet (COSTA et al., 2011). The species is allogamous with probable autoincompatibility; it presents hermaphrodite flowers and floral opening in the nocturnal period, occurring pollination mainly by bats that are able to fly for long distances (DUNPHY et al., 2004).

Additionally, $H$. courbaril is one of the most important timber species, being widely exploited in the Amazon. However, studies performed by Lacerda et al., 2008a and Carneiro et al., 2011 reported that spatial genetic structure and genetic diversity of this species has been affected by logging.

In this study, we analyzed the genetic diversity of natural populations of Hymenaea courbaril in the Mato Grosso Amazon, which in the last decades was impacted by habitat loss, fragmentation, logging and construction of highways. The objective of our study was to answer following two questions: (1) what is level of genetic diversity and genetic structure of these population of $H$. courbaril? (2)What are implications of these findings for the conservation of genetic resources of the species? Our hypothesis was that the fragmentation process and the forest exploitation promote the restriction of gene flow, consequently increasing the levels of inbreeding and reducing the genetic variability in the natural populations of $H$. courbaril. To address these objectives and hypothesis, we used microsatellite markers to genotyped samples from different populations.

\section{MATERIAL AND METHODS}

\section{Study location}

The study was carried out in the north region of Mato Grosso State, Brazil, involving five locations in the municipalities of Alta Floresta (AF), Colíder (CL), Marcelândia (MA), Nova Monte Verde (MV), and Sinop (SP) (Figure 1). The climate in the area is classified by the Köppen (1936) system as an Am type, with an annual precipitation of approximately 3,000, average annual temperature higher than $24{ }^{\circ} \mathrm{C}$, and altitudes ranging from 200 to 400 m (ALVARES et al., 2012; ALVARES et al., 2014).

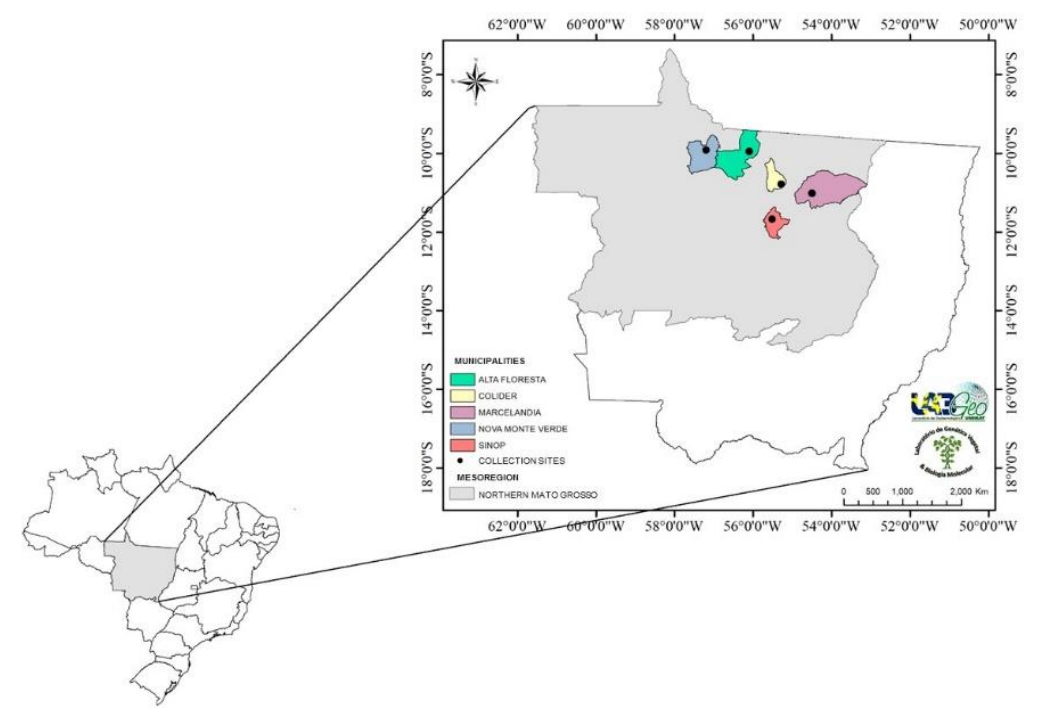

Figure 1. Geographic distribution of the Hymenaea courbaril collection sites in northern Mato Grosso State, Brazil.

Figura 1. Distribuição geográfica das localidades de coletas de Hymenaea courbaril no norte do estado de Mato Grosso, Brasil.

FLORESTA, Curitiba, PR, v. 49, n. 4, p. 745 - 754, out/dez 2019 
Forty-three adult $H$. courbaril trees naturally occurring in the five locations were sampled, as shown in Table 1. Each locality constituted one population. We sampled individuals separated geographically for a minimum of 400 meters in each locality. These individuals were collected in grazing areas in the roadsides.

Table 1. Hymenaea courbaril collection (AF, CL, MA, MV, SP), followed by respective identification code, number of trees used in the molecular analyses, and geographic coordinates

Tabela 1. Localidades de coletas de Hymenaea courbaril (AF, CL, MA, MV, SP), seguidas pelo respectivo código de identificação, número de árvores utilizadas nas análises moleculares e coordenadas geográficas.

\begin{tabular}{lccll}
\hline Location & Code & N of trees & Latitude $(\mathbf{S})$ & Longitude $(\mathbf{W})$ \\
\hline Alta Floresta, MT & AF & 10 & $9^{\circ} 57^{\prime} 0.8^{\prime \prime}$ & $56^{\circ} 5^{\prime} 54^{\prime \prime}$ \\
Colíder, MT & CL & 9 & $10^{\circ} 47^{\prime} 14.4^{\prime \prime}$ & $55^{\circ} 17^{\prime} 17.1^{\prime \prime}$ \\
Marcelândia, MT & MA & 10 & $11^{\circ} 0^{\prime} 52^{\prime \prime}$ & $54^{\circ} 30^{\prime} 2.81^{\prime \prime}$ \\
Nova Monte Verde, MT & MV & 7 & $9^{\circ} 55^{\prime} 7.2^{\prime \prime} \mathrm{S}$ & $57^{\circ} 11^{\prime} 58^{\prime \prime}$ \\
Sinop, MT & SP & 7 & $11^{\circ} 40^{\prime} 45^{\prime \prime S} ;$ & $55^{\circ} 30^{\prime} 47^{\prime \prime}$ \\
\hline
\end{tabular}

\section{Collection of plant material}

For the extraction of genetic material, young leaves were harvested from each individual in the years 2016 and 2017. In the field, all leaf samples were properly identified and wrapped in zip-lock plastic bags containing silica gel that were later sent to the Laboratory of Plant Genetics and Molecular Biology (GenBioMol) of the State University of Mato Grosso, Alta Floresta Campus, where they were stored in a freezer $\left(-20^{\circ} \mathrm{C}\right)$ until a subsequent DNA extraction process.

\section{DNA extraction and microsatellite analyses}

The genomic DNA was extracted from $1 \mathrm{~g}$ of leaf tissue, using the CTAB method proposed by Doyle \& Doyle (1987). Quantification and integrity assessment of the extracted DNA were performed via horizontal electrophoresis on ethidium bromide-stained $1 \%$ agarose gel $(10 \mathrm{mg} / \mathrm{mL})$. For quantification, $\lambda$-DNA molecular weight markers $(100$ and $50 \mathrm{ng} / \mu \mathrm{L})$ were used. DNA samples were diluted in autoclaved distilled water and standardized at the concentration of $5 \mathrm{ng} / \mu \mathrm{L}$.

Seven microsatellite primers developed for the species $H$. courbaril were used in the genetic analysis four of them described by Ciampi et al., (2008) and three developed by EMBRAPA Recursos Genéticos e Biotecnologia (Table 2). PCR amplification reactions were conducted at a final volume of $13 \mu \mathrm{L}$, containing $2 \mu \mathrm{L}$ DNA $(5 \mathrm{ng} / \mu \mathrm{L}), 1.5 \mu \mathrm{L} 10 \mathrm{X}$ buffer (10 mM Tris-HCl (pH 8.3), $50 \mathrm{mM}$ potassium chloride, and $0.1 \%$ Tween-20), $0.50 \mu \mathrm{L} \mathrm{MgCl}_{2}(50 \mathrm{mM}), 3 \mu \mathrm{L}$ dNTPs $(1 \mathrm{mM}), 2 \mu \mathrm{L}$ of each primer $(2 \mu \mathrm{M}), 0.12 \mu \mathrm{L}$ Taq DNA polymerase, and $1.88 \mu \mathrm{L}$ distilled autoclaved water.

Table 2. Description of the seven microsatellite primers used for the genetic analyses in Hymenaea courbaril Tabela 2. Descrição dos sete primers microssátelites utilizados para as análises genéticas em Hymenaea courbaril.

\begin{tabular}{|c|c|c|c|c|}
\hline Primer & 5'- 3' sequence & Motive & AT $\left({ }^{\circ} \mathbf{C}\right)$ & Allele range \\
\hline $\mathrm{Hc} 12^{1}$ & $\begin{array}{l}\text { F: TGTTCCAATTTATGTCCATGGTT } \\
\text { R: TGGATGGTTGTGAAGAAAAGG }\end{array}$ & $(\mathrm{TC})_{21}$ & 58 & $130-232$ \\
\hline $\mathrm{Hc} 14^{1}$ & $\begin{array}{l}\text { F: CATTCTGCCATCGGTAGGTT } \\
\text { R: TCACCCAAACAGGAGTGAA }\end{array}$ & $(\mathrm{TC})_{17}$ & 56 & $90-124$ \\
\hline $\mathrm{Hc} 33^{1}$ & $\begin{array}{l}\text { F: GAACAAATCAACTTTCTTTGAAGC } \\
\text { R: TTGACGCTTATTTTGCACCA }\end{array}$ & $(\mathrm{AG})_{16}$ & 60 & $100-118$ \\
\hline $\mathrm{Hc} 35^{2}$ & $\begin{array}{l}\text { F: CTTGCACCTTTCACCCATTT } \\
\text { R: CTCTTTGCTTCCСТCTCCCT }\end{array}$ & $*$ & 58 & $256-298$ \\
\hline $\mathrm{Hc} 40^{1}$ & $\begin{array}{l}\text { F: CСТСТСТCСCAAATTCACGA } \\
\text { R: TGCAATAGAATTTCCGAGGC }\end{array}$ & $(\mathrm{AG})_{26}$ & 56 & $161-255$ \\
\hline $\mathrm{Hc} 48^{2}$ & $\begin{array}{l}\text { F: TTCCTTTCTTTGGTACTGTTGG } \\
\text { R: CAAACTTCATTCTCCATCTTTTC }\end{array}$ & $*$ & 56 & $116-220$ \\
\hline $\mathrm{Hc} 49^{2}$ & $\begin{array}{l}\text { F: CCACCTCTCTCCACCCAATA } \\
\text { R: TCCGGGAACTGCTTAATTTG }\end{array}$ & $*$ & 60 & $76-172$ \\
\hline
\end{tabular}

${ }^{1}$ primers described by Ciampi et al. (2008); ${ }^{2}$ primers developed by Embrapa Recursos Genéticos e Biotecnologia; *data not published. 
Amplifications were carried out using a thermocycler (Aeris $\left.{ }^{\mathrm{TM}}\right)$ and the software proposed by Silva et al. (2014), consisting of an initial denaturation cycle at $94{ }^{\circ} \mathrm{C}$ for $5 \mathrm{~min}$, followed by 30 cycles at $94{ }^{\circ} \mathrm{C}$ for $1 \mathrm{~min}$, specific primer annealing temperature for $1 \mathrm{~min}$ and $72{ }^{\circ} \mathrm{C}$ for $1 \mathrm{~min}$, and a final extension of $72{ }^{\circ} \mathrm{C}$ for $5 \mathrm{~min}$.

Amplification products were separated by horizontal electrophoresis on $2 \%$ agarose gel with $1 \mathrm{X}$ TBE ( $89.15 \mathrm{mM}$ Tris Base; $88.95 \mathrm{mM}$ boric acid, and $2.23 \mathrm{mM}$ EDTA), with a voltage of $80 \mathrm{v}$. After electrophoresis, the gels were ethidium bromide-stained $(0.6 \mathrm{ng} / \mathrm{mL})$ and then photographed under ultraviolet light using the LOCCUS (LTB-20X20 STi) gel documentation system.

\section{Statistical analysis}

The amplified fragments were analyzed by LabImage 1D software for constructing the matrix, based on the size of the alleles of the samples. The matrix was open in Power Marker V.3.25 software to estimate the total number of alleles, the average number of alleles per locus, gene diversity $\left(G_{D}\right)$, expected heterozygosity $\left(H_{E}\right)$, observed heterozygosity $\left(H_{O}\right)$, polymorphic information content (PIC), and fixation index $(f)$. The presence of rare and private alleles was determined using GenAlEx 6.5 software.

Analysis of molecular variance (AMOVA) is a method that evaluates the distribution of genetic variability within and among populations. This analysis was undertaken using Arlequim 3.01 software, and the significance of genetic differentiation was tested with 1,000 permutations.

Nei (1983)'s genetic distance matrix generated by Power Marker V.3.25 software was imported to MEGA 3.1 software, where a dendrogram was constructed by the UPGMA (Unweighted Pair-Group Method with Arithmetic Mean) method. Bayesian analysis, performed using Structure 2.3.4. software, was employed to infer the number of $H$. courbaril gene groups. Twenty runs with 250,000 burn-ins and 750,000 Markov chain Monte Carlo (MCMC) simulations were performed and results were sent to Structure Harvest to calculate $\Delta \mathrm{K}$. Genotypes were grouped according to the number of groups $(\mathrm{K})$ proposed by Evanno et al. (2005)'s $\Delta \mathrm{K}$ method.

\section{RESULTS}

All primers used revealed polymorphisms, producing clear and well-defined bands. The number of alleles amplified in the $43 \mathrm{H}$. courbaril genotypes was 72 , with an average of 10.29 , ranging from 7 (Hc14, Hc33, and Hc35) to 14 (Hc48) (Table 3).

Average gene diversity was 0.94 per primer, confirming that the SSR loci are highly variable (Table 3 ). Expected heterozygosity ranged from 0.78 (Hc35) to 0.90 (Hc40 and Hc48), averaging 0.85 . The lowest observed heterozygosity values were found in loci $\mathrm{Hc14}$ and Hc33, while the highest (0.90) was detected in Hc40. Polymorphic information content (PIC) values ranged from 0.77 (Hc14) to 0.89 (Hc40 and Hc48), averaging 0.83.

Table 3. Number of alleles $\left(N_{\mathrm{A}}\right)$, gene diversity $\left(\mathrm{G}_{D}\right)$, expected heterozygosity $\left(H_{E}\right)$, observed heterozygosity $\left(H_{o}\right)$, and polymorphic information content (PIC) of seven primers used for the genotyping of 43 Hymenaea courbaril individuals from five populations located in northern Mato Grosso State, Brazil.

Tabela 3. Número de alelos $\left(N_{\mathrm{A}}\right)$, diversidade gênica, $\left(\mathrm{D}_{G}\right)$, heterozigosidade esperada $\left(H_{E}\right)$, heterozigosidade observada $\left(H_{o}\right)$ e índice de conteúdo polimórfico (PIC) de sete primers utilizados para genotipagem de 43 indivíduos de Hymenaea courbaril pertencentes a cinco populações localizadas no norte do estado de Mato Grosso, Brasil.

\begin{tabular}{lccccc}
\hline Primer & $\boldsymbol{N}_{\boldsymbol{A}}$ & $\boldsymbol{G}_{\boldsymbol{D}}$ & $\boldsymbol{H}_{\boldsymbol{E}}$ & $\boldsymbol{H}_{\boldsymbol{O}}$ & PIC \\
\hline Hc12 & 12 & 0.93 & 0.87 & 0.20 & 0.86 \\
Hc14 & 7 & 0.86 & 0.80 & 0.00 & 0.77 \\
Hc33 & 7 & 0.98 & 0.82 & 0.00 & 0.80 \\
Hc35 & 7 & 0.95 & 0.78 & 0.17 & 0.75 \\
Hc40 & 13 & 0.95 & 0.90 & 0.90 & 0.89 \\
Hc48 & 14 & 0.95 & 0.90 & 0.40 & 0.89 \\
Hc49 & 12 & 0.93 & 0.87 & 0.29 & 0.86 \\
\hline Average & 10.29 & 0.94 & 0.85 & & 0.83 \\
\hline Total & 72 & & & \\
\hline
\end{tabular}


In the analyses conducted separately for each population (Table 4), a higher average number of alleles (5.29) was observed in AF and CL, whereas the lowest (3.79) was found in MV. Gene diversity was high (>0.80) in all populations sampled. Observed heterozygosity was lower than expected heterozygosity, with a positive and high fixation index. Four rare alleles were detected in AF and MA, the former having three and the latter one rare allele. Twenty-six private alleles were found across the five populations.

Table 4. Genetic diversity: average number of alleles $(N)$, gene diversity $\left(G_{D}\right)$, expected heterozygosity $\left(H_{E}\right)$, observed heterozygosity $\left(H_{o}\right)$, fixation index $(f)$, rare alleles $(A r)$, and private alleles $(A p)$ for populations of Hymenaea courbaril sampled in Alta Floresta (AF), Colíder (CL), Marcelândia (MA), Nova Monte Verde (MV), and Sinop (SP) in northern Mato Grosso State, Brazil.

Tabela 4. Diversidade genética: Número médio de alelos $(N)$, diversidade gênica, $\left(D_{G}\right)$, heterozigosidade esperada $\left(H_{E}\right)$, heterozigosidade observada $\left(H_{o}\right)$, índice de fixação $(f)$, alelo raro $(A r)$ e alelo privado $(A p)$ para populações de Hymenaea courbaril amostradas em Alta Floresta (AF), Colíder (CL), Marcelândia (MA), Nova Monte Verde (MV) e Sinop (SP) no norte de Mato Grosso, Brasil.

\begin{tabular}{lccccccc}
\hline Population & $\boldsymbol{N}$ & $\boldsymbol{G}_{\boldsymbol{D}}$ & $\boldsymbol{H}_{\boldsymbol{E}}$ & $\boldsymbol{H o}$ & $\boldsymbol{f}$ & $\boldsymbol{A r}$ & $\boldsymbol{A p}$ \\
\hline AF & 5.29 & 0.97 & 0.76 & 0.30 & 0.64 & 3 & 7 \\
CL & 5.29 & 0.98 & 0.72 & 0.30 & 0.62 & 0 & 5 \\
MA & 4.29 & 0.86 & 0.67 & 0.20 & 0.73 & 1 & 8 \\
MV & 3.71 & 0.96 & 0.62 & 0.39 & 0.44 & 0 & 2 \\
SP & 4.14 & 0.92 & 0.56 & 0.30 & 0.53 & 0 & 4 \\
\hline Total & & & & & 4 & 26 \\
\hline
\end{tabular}

Analysis of molecular variance (AMOVA) revealed that $14.67 \%$ of genetic variation is among the populations and $85.33 \%$ is within the populations analyzed for $H$. courbaril (Table 5).

Table 5 Analysis of molecular variance (AMOVA) for five populations of Hymenaea courbaril in northern Mato Grosso State, Brazil. Degrees of freedom (d.f.); sum of squares; (SS); coefficient of variation (CV); total variation (TV).

Tabela 5 Análise de variância molecular (AMOVA) para as cinco populações de Hymenaea courbaril no norte do estado de Mato Grosso, Brasil. Grau de Liberdade (GL), Soma dos Quadrados (SQ), Componente de Variância (CV) e Variância Total (VT).

\begin{tabular}{lccccc}
\hline Source of variation & d.f. & SS & CV & TV (\%) & P value \\
\hline Among populations & 4 & 21.90 & 0.24 & 14.67 & $<0.0001$ \\
Within populations & 81 & 112.55 & 1.39 & 85.33 & \\
\hline Total & 85 & 134.45 & 1.63 & & \\
\hline
\end{tabular}

Probabilities were calculated by 1000 permutations

The dendrogram generated by the UPGMA method had the genotypes divided into six groups, with different levels of genetic dissimilarity (Figure 2). Group I contained six individuals (MA4, MA5, MA6, MA2, MA10, and MA9); group II had four (CL4, AF3, AF2, and AF7); group III was composed of five plants (AF5, AF6, MA7, AF1, and SP5); and group IV included seven plants (MA1, MA3, AF10, SP1, SP7, SP4, and SP6). The largest clusters were V and VI, which were formed by 13 (AF8, CL6, CL7, CL3, CL1, CL2, AF9, MA8, MV3, MV6, AF4, CL8, and CL9) and eight genotypes (CL5, SP2, SP3, MV2, MV4, MV5, MV1, and MV7), respectively. 


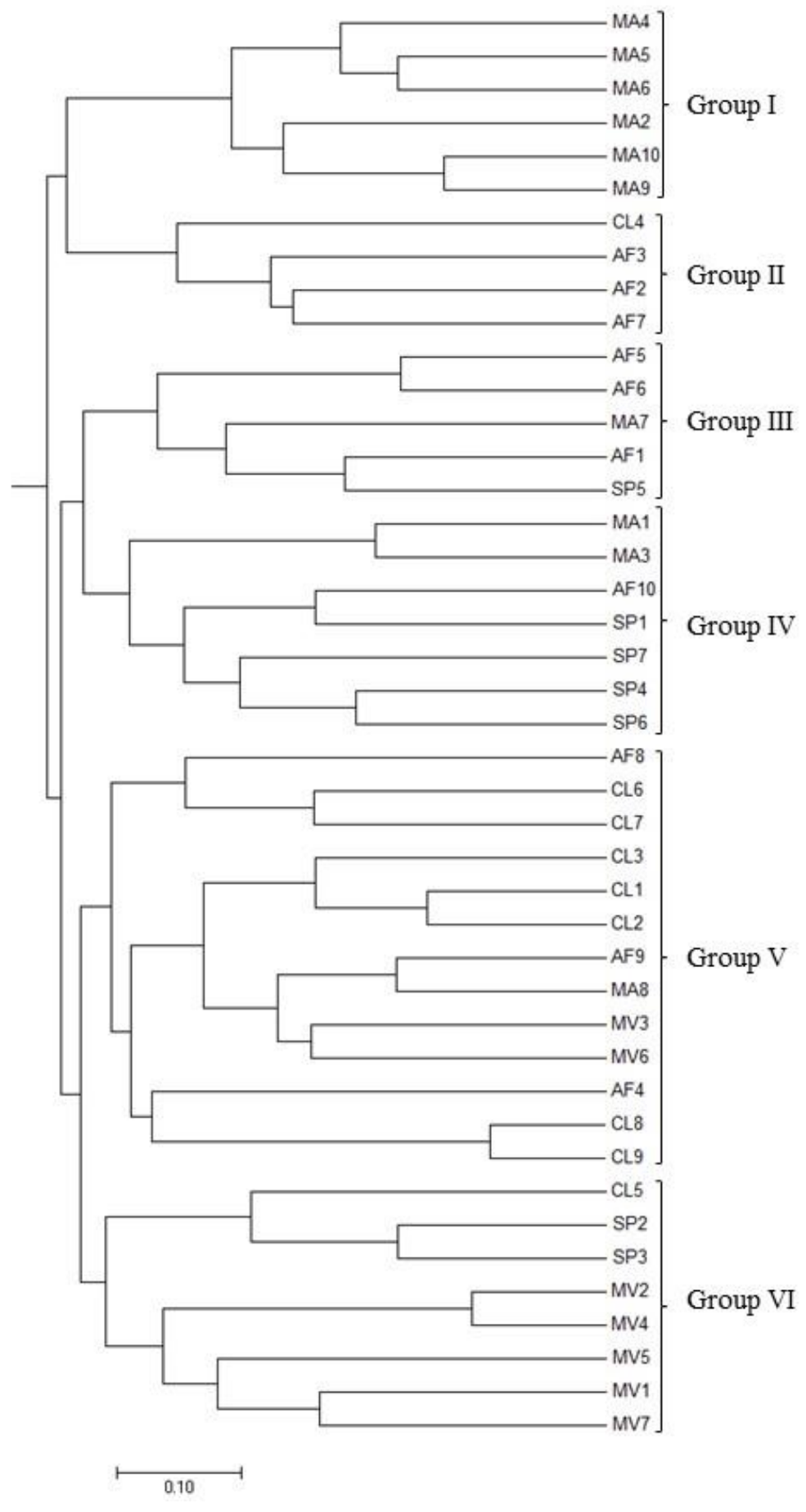

Figure 2. UPGMA dendrogram showing the genetic relationships among 43 Hymenaea courbaril genotypes sampled in five populations in the municipalities of Alta Floresta (AF), Colíder (CL), Marcelândia (MA), Nova Monte Verde (MV), and Sinop (SP) in northern Mato Grosso State, Brazil.

Figura 2. Dendrograma UPGMA, mostrando as relações genéticas entre 43 genótipos de Hymenaea courbaril amostrados em cinco populações nos municípios de Alta Floresta (AF), Colíder (CL), Marcelândia (MA), Nova Monte Verde (MV) e Sinop (SP) no norte do estado de Mato Grosso, Brasil.

According to the Bayesian analysis, four groups were formed $(\mathrm{K}=4)$ (Figure 3$)$. The constitution of these groups did not correspond to the geographic distribution of the genotypes, suggesting there is no genetic structuring in geographical terms. 


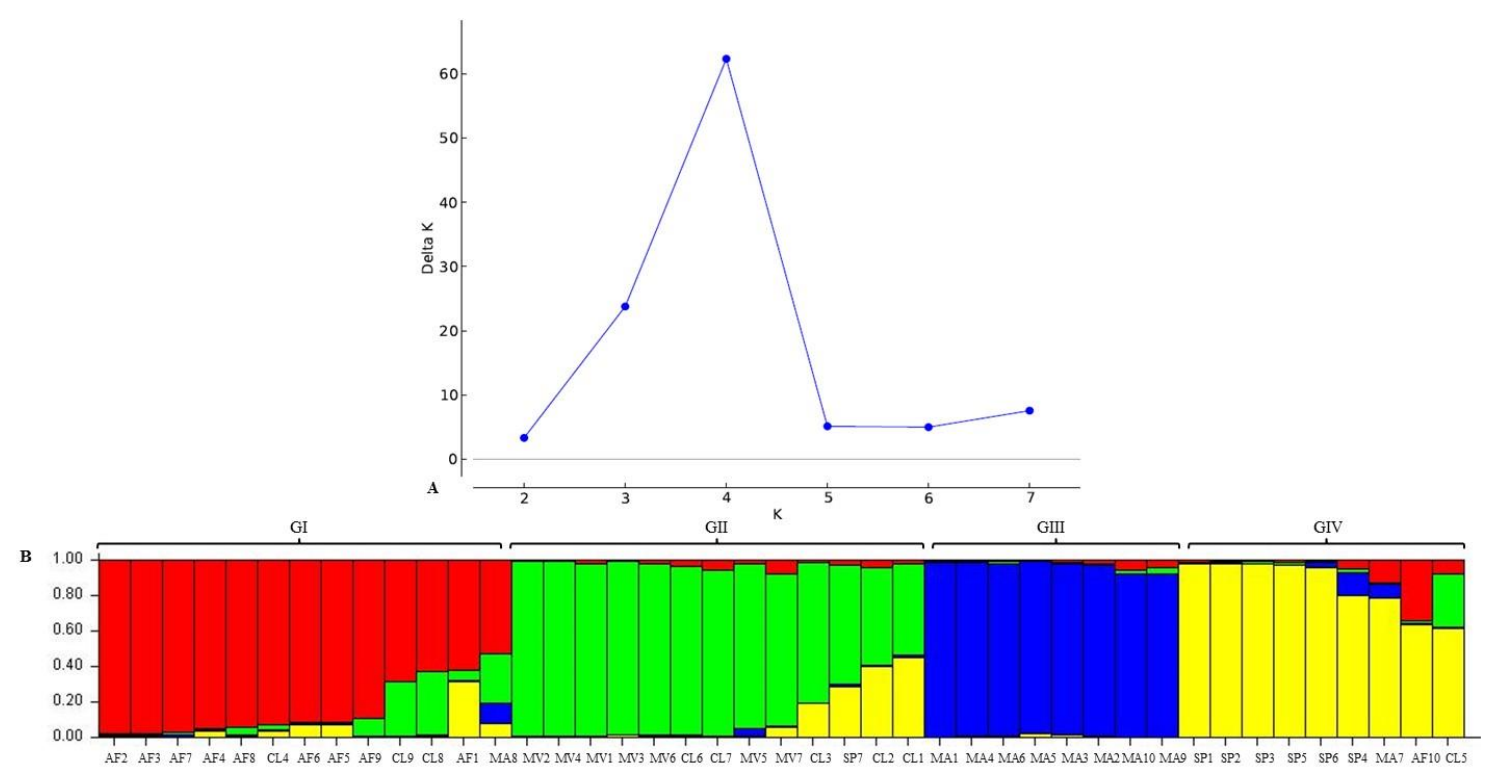

Figure 3. Cluster analysis by Structure software. A) Most probable number of groups $(K=4)$ calculated by the $\Delta K$ method, according to Evanno et al. (2005). B) Distribution of the 43 Hymenaea courbaril genotypes. Vertical lines represent the individuals and are divided into colored segments based on genotypic similarity in relation to the groups created by the software.

Figura 3. Análise de agrupamento pelo programa Structure. A) Número de grupos mais provável (K=4), calculado pelo método $\Delta \mathrm{K}$ de acordo com Evanno et al. (2005). B) Distribuição dos 43 genótipos de Hymenaea courbaril. As linhas verticais representam os indivíduos e são divididas em segmentos coloridos, baseados na semelhança genotípica em relação aos grupos inferidos pelo programa.

\section{DISCUSSION}

By comparing the results obtained for expected heterozygosity with the studies of Lacerda et al. (2008a) and Silva et al. (2014) on genetic diversity in H. courbaril in the Amazon using microsatellite markers, we observe that the present findings are in line the standards for the species. In $\mathrm{H}$. courbaril, the expected heterozygosity has been greater than 0.70 , on average, which is considered high.

All the primers used in this study were highly informative, as they showed a PIC greater than 0.50 , which means they were efficient in discriminating $H$. courbaril genotypes. The PIC estimates the discriminatory power of a locus, indicating the utility potential of the marker for genetic diversity analysis. "Markers with high PIC values have elevated potential to reveal allelic variation (SPANDANA et al., 2012)". Therefore, the use of these primers is recommended in future research evaluating genetic diversity in the species. Additionally, Carneiro et $a l ., 2012$ verified that theses primers ( $\mathrm{Hc} 12, \mathrm{Hc} 14, \mathrm{Hc} 33$ and Hc40) used here follow Mendelian inheritance pattern and showed no linkage or genotypic disequilibrium.

Gene diversity was high in all studied populations, expressing the existence of wide genetic variability. Despite the reduction of $H$. courbaril populations caused by logging, these results show that there is still considerable genetic diversity in its populations, which can be attributed to the high level of cross-fertilization promoted by pollinators (bats), probable self-incompatibility system, hermaphrodite flowers, long life cycle of individuals, and wide geographical distribution. These traits help to maintain genetic diversity of the species.

Observed heterozygosity was lower than expected heterozygosity, consequently generating a positive and high fixation index. An elevated fixation index indicates the existence of crossing between related individuals, suggesting inbreeding in the populations and consequently excess homozygotes (loss of genetic diversity), which in future may jeopardize the evolutionary potential of the species. The inbreeding may be related to forest fragmentation; it causes both the reduction of the number of populations and the density of reproductive trees, limiting the gene flow by isolation. The areas sampled in this study are located in an agricultural frontier region that has undergone intense fragmentation and loss of natural vegetation, leading to isolation of populations. In the

FLORESTA, Curitiba, PR, v. 49, n. 4, p. 745 - 754, out/dez 2019.

Rocha, V. D. et.al.

ISSN eletrônico 1982-4688

DOI: $10.5380 /$ rf.v49 i4.58484 
north region of Mato Grosso, the genetic diversity of native species like Theobroma speciosum Willd. ex Spreng has been negatively affected by habitat fragmentation (DARDENGO et al., 2018).

Private alleles were found in the five populations of $H$. courbaril. According to Kalinowski (2004), the number of private alleles present in the populations is useful for developing genetic conservation strategies, contributing to the selection of populations that deserve special management. Thus, it can be stated that the analyzed populations have conservation potential.

AMOVA results showed a greater genetic differentiation within the populations, which is a common behavior in allogamous species like jatobá, which has a high degree of cross-fertilization and signs of selfincompatibility (LACERDA et al., 2008b). The reproductive system of a species influences the distribution of genetic variation among and within populations. In $H$. courbaril, where gene are transmitted from one generation to another through cross-pollination, Resende-Moreira et al. (2017) observed high intrapopulation genetic diversity (>60\%).

The cluster analyses (UPGMA and Bayesian Analysis) revealed different genetic groups constituting the sampling, whose compositions demonstrate there is no relationship between genetic distance and geographic distance. Thus, the genotypes originating from populations geographically closer are not necessarily the most genetically similar. A hypothesis raised in this situation is that, in previous generations, before the fragmentation process started in 1970 with the opening of highways, there gene flow had occurred among the populations. Jatobá seeds and fruits are consumed by mammals such as monkeys, deer, and tapirs (COSTA et al., 2015), which facilitates the dispersion of this species across long distances.

\section{CONCLUSIONS}

- The populations sampled for H. courbaril should be conserved so that its elevated genetic diversity can be preserved, which is important for evolutionary potential.

- Genetic variation is higher within the studied populations, requiring the conservation of several individuals per population.

- Because there is genetic diversity among $H$. courbaril genotypes, they may be used for germplasm collection, given the ex situ conservation.

- The effect of fragmentation may be influencing the genetic diversity of $H$. courbaril, favoring inbreeding and an increase in the number of homozygotes in the analyzed populations. To prevent the occurrence of inbreeding, measures should be adopted aiming at gene exchange between populations, e.g., implementation of ecological corridors.

- To add more information about genetics and population dynamics of the species, we recommend the collection of seeds from these individuals to perform studies of reproductive system, analysis of pollen and seeds gene flow and effective size estimation.

\section{ACKNOWLEDGMENTS}

The authors thank the Mato Grosso Research Support Foundation (Fundação de Amparo à Pesquisa do Mato Grosso - FAPEMAT) for the financial support for the project entitled "Conservation and use of native plant species of the Amazon region with economic potential for northern Mato Grosso State" (no. 166159/2014). Vinicius Delgado da Rocha thanks the National Council for Scientific and Technological Development (Nacional de Desenvolvimento Científico e Tecnológico - CNPq) for the undergraduate research fellowship grant.

\section{REFERENCES}

ALVARES, C. A.; STAPE, J. L.; SENTELHAS, P. C.; GONÇALVES, J. L. M.; SPAROVEK, G. Köppen's climate classification map for Brazil. Meteorologische Zeitschrift, Stuttgart, v.22, n.6, p.711-728, 2014.

ALVARES, C. A.; STAPE, J. L.; SENTELHAS, P. C.; GONÇALVES, J. L. M. Modeling monthly mean air temperature for Brazil. Theoretical and Applied Climatology, v.113, p.407-427, 2012.

BEECH, E.; RIVERS, M.; OLDFIELD, S.; SMITH, P. P. GlobalTreeSearch - the first complete global database of tree species and country distributions. Journal of Sustainable Forestry, v.36, p.454-489, 2017. 
BITTENCOURT, J. V. M. Proposta para conservação genética da Araucaria angustifolia. Pesquisa Florestal Brasileira, Colombo, n.55, p.87-93, 2007.

CARDOSO, D. et al. Amazon plant diversity revealed by a taxonomically verified species list. Proceedings of the National Academy of Sciences, Washington, v.114, n.40, p.10695-10700, 2017.

CARVALHO, A. C. M.; FREITAS, M. L. M.; MORAES, S. M. B.; MORAES, M. L. T.; STRANGHETTI, V.; ALZATE-MARIN, A. L.; SEBBENN, A. M. Diversidade genética, endogamia e fluxo gênico em pequena população fragmentada de Copaifera langsdorffii. Revista Brasileira de Botânica, São Paulo, v. 33, n. 4, p. 599$606,2010$.

CARNEIRO, F S.; LACERDA, A. E. B.; LEMES, M. R.; GRIBEL, R.; KANASHIRO, M.; SEBBENN, A. M. Mendelian inheritance, linkage and genotypic disequilibrium in microsatellite loci isolated from Hymenaea courbaril (Leguminosae). Genetics and Molecular Research, Ribeirão Preto, v. 11, n. 3, p. 1942-1948, 2012.

CARNEIRO, F. S.; LACERDA, A. E. B.; LEMES, M. R.; GRIBEL, R.; KANASHIRO, M.; WADT, L. H. O.; SEBBENN, A. M. Effects of selective logging on the mating system and pollen dispersal of Hymenaea courbaril L. (Leguminosae) in the Eastern Brazilian Amazon as revealed by microsatellite analysis. Forest Ecology and Management, v. 262, p. 1758-1765, 2011

CIAMPI, A. Y.; AZEVEDO, V. C. R.; GAIOTTO, F. A.; RAMOS, A. C. S.; LOVATO, M. B. Isolation and characterization of microsatellite loci for Hymenaea courbaril and transferability to Hymenaea stigonocarpa, two tropical timber species. Molecular Ecology Resources, v.8, n.5, p.1074-1077, 2008.

COSTA, C. B.; CASTEllani, D. C.; SOUZA, A. L.; SILVA, A. C. Boas práticas de manejo para o extrativismo sustentável do Jatobá. Brasília: Instituto Sociedade, População e Natureza, 2015. 76 p

COSTA, W. S.; SOUZA, A. L.; SOUZA, P. B. Ecologia, Manejo, Silvicultura e Tecnologia de espécies nativas da Mata Atlântica. Viçosa: Espécies nativas da Mata Atlântica, n. 2, 2011. 18 p.

COTA, L. G.; MOREIRA, P. A.; BRANDÃO, M. M.; ROYO, V. A.; MELO JUNIOR, A. F.; MENEZES, E. V.; D. A. OLIVEIRA. Structure and genetic diversity of Anacardium humile (Anacardiaceae): a tropical shrub. Genetics and Molecular Research, Ribeirão Preto, v.16, n.3, p.1-13, 2017.

DARDENGO, J. F. E.; ROSSI, A. A. B.; VARELLA, T. L. The effects of fragmentation on the genetic structure of Theobroma speciosum (Malvaceae) populations in Mato Grosso, Brazil. Revista de Biologia Tropical, San José, v.66, n.1, p.218-226, 2018.

DOYLE, J. J.; DOYLE, J. L. A rapid DNA isolation procedure for small amounts of fresh leaf tissue. Phytochemical Bulletin, v.19, p.11-15, 1987.

DUNPHY, B. K.; HAMRICK, J. L.; SCHWAGERL, J. A comparison of direct and indirect measures of gene flow in the bat-pollinated tree Hymenaea courbaril in the dry forest life zone of south-western Puerto Rico. International Journal of Plant Sciences, Chicago, v. 165, n.3, p. 427-436, 2004.

EVANNO, G.; REGNAUT , S.; GOUDET , J. Detecting the number of clusters of individuals using the soft ware STRUCTURE: a simulation study. Molecular Ecology, v.14, p.2611-2620, 2005.

GONÇALVES; A. C.; VIEIRA, F. A.; REIS, C. A. F.; CARVALHO, D. Conservação de Dimorphandra mollis Benth. (Fabaceae) baseada na estrutura genética de populações naturais. Revista Árvore, Viçosa, v.34, n.1, p.95$101,2010$.

KAGEYAMA, P.Y.; GANDARA, F.B. Conseqüências genéticas da fragmentação sobre populações de espécies arbóreas. Série técnica IPEF, Piracicaba, v.12, n.32, p.65-70, 1998.

KALINOWSK, S. T. Counting alleles with rarefaction: Private alleles and hierarchical sampling designs. Conservation Genetics, Netherlands, v.5, n.4, p.539-543, 2004.

LACERDA, A. E. B.; KANASHIRO, M.; SEBBENN, A. Long-pollen movement and deviation of random mating in a low-density continuous population of a tropical tree Hymenaea courbaril in the Brazilian Amazon. Biotropica, Lawrence, v.40, n.4, p.462-470, 2008 b.

FLORESTA, Curitiba, PR, v. 49, n. 4, p. 745 - 754, out/dez 2019

Rocha, V. D. et.al.

ISSN eletrônico 1982-4688

DOI: $10.5380 /$ rf.v49 i4.58484 
LACERDA, A. E. B.; KANASHIRO, M.; SEBBENN, A. M. Effects of reduced impact logging on genetic diversity and spatial genetic structure of a Hymenaea courbaril population in the Brazilian Amazon Forest. Forest Ecology and Management, Amsterdam, v. 255, n.3-4, p.1034-1043, 2008a

RESENDE-MOREIRA, L. C.; RAMOS, A. C. S.; SCLIAR, M. O.; SILVA, R. M.; AZEVEDO, V. C. R.; CIAMPI, A. Y.; LEMOS-FILHO, J. P.; LOVATO, M. B. Gene flow between vicariant tree species: insights into savannaforest evolutionary relationships. Tree Genetics \& Genomes, v.13, p.1-15, 2017.

SILVA, B. M.; ROSSI, A. A. B.; TIAGO, A. V.; SCHMITT, K. F. M.; DARDENGO, J. F. E.; SOUZA, S. A. M. Genetic diversity of Cajazeira (Spondias mombin L.) in three geographic regions. Genetics and Molecular Research, Ribeirão Preto, v.16, n.1, p.1-11, 2017.

SILVA, S. M. M.; MARTINS, K.; MESQUITA, A. G. G.; WADT, L. H. O. Parâmetros genéticos para a conservação de Hymenaea courbaril 1. na Amazônia Sul-Ocidental. Ciência Florestal, Santa Maria, v.24, n.1, p.87-95, 2014.

SPANDANA, B.; REDDY V. P.; PRASANNA G. J, ANURADHA G.; SIVARAMAKRISHNAN, S. Development and characterization of microsatellite markers (SSR) in Sesamum (Sesamum indicum L.) species. Applied Biochemistry and Biotechnology, v.168, n.6, p.1594-1607, 2012. 